\title{
RECLAMATION OF DERELICT INDUSTRIAL LAND IN PORTUGAL: GREENING IS NOT ENOUGH
}

\author{
L. LOURES ${ }^{1,2} \&$ T. PANAGOPOULOS ${ }^{2}$ \\ ${ }^{1}$ Politechnic Institute of Portalegre - ESAE, Quartel do Trem, Elvas, Portugal. \\ ${ }^{2}$ Research Centre for Spatial and Organizational Dynamics (CIEO), University of Algarve, Faro, Portugal.
}

\begin{abstract}
A negative effect of the globalization on industry over the past decades was a vast array of obsolete industrial facilities and the various impacts, which were generated from them. In this context, abandonment, sale or demolition of such facilities, were fairly common approaches. However, the creation of new and more severe environmental legislation, the high price of urban land, and the public pressure related with the need to protect the environment, increased the number of post-industrial sites that returns to productive use. Within every problem there is an opportunity. Derelict and contaminated industrial sites have high potential for urban regeneration, ecological restoration and reintegration into the surrounding community. To exemplify the importance of those spaces in the urban landscape, this paper will analyze two industrial reclamation projects realized in Portugal during the last decade (Parque Tejo-Trancão - Expo 98 and Braga Stadium - Euro 2004). The significance of these projects in achieving a sustainable urban landscape is discussed. This article shows that the industrial landscape should be viewed as a resource and its recovery as an opportunity to develop new multifunctional landscapes in which new forests are indispensable.
\end{abstract}

Keywords: brownfield, city regeneration, design, land recycling, landscape reclamation.

\section{INTRODUCTION}

'In the opening years of the twenty-first century, that seemingly old-fashioned term landscape has curiously come back to vogue' [1] along with the necessity to reclaim derelict landscapes in detriment of consuming new landscapes. For this reason, 'Industry, the source of every evil and every good, became one of the main protagonists in the transformation of the city' [2]. In this context the effects of the globalization of industry over the past decades had a profound effect on the traditional industrial areas all over the world and produced a vast array of obsolete industrial facilities with various impacts generated from them [3]. The formal products of the modernist movement have become obsolete, forcing this generation to decide on the disposition of the last generation's industrial environment. Furthermore the international industrial climate, which some have termed as the 'third industrial revolution' [4], has rendered obsolete industrial structures, technologies and processes of the first half of the twentieth century. Abandonment, sale and demolition of such spaces were fairly common approaches to deal with facilities that were designated as 'surplus' no longer serving their original production functions [5].

However, the creation of new and more severe environmental legislation, and the public pressure related with the need to protect the environment, increased the necessity of converting post-industrial sites into multifunctional landscapes [6]. Derelict and contaminated industrial sites are unrealized resources for initiating urban regeneration and ecological restoration [7-9]. These sites are often in advantageous locations near city centers, along waterfronts, supported by existing infrastructure and adjacent to residential communities. These landscapes are environmentally impaired assets that need to be returned to productive use, and reintegrated into the surrounding community. Therefore, if this landscape reclamation work was made at a larger scale and across multiple sites, this effort could restore natural processes and functions, regenerate several areas of the city, create multifunctional landscapes and promote sustainable growth [10]. 
We believe that there exist many places in the world where Man have destroyed Nature, and then, being aware of what he was doing, have tried to fix it. We think that people, in general, must be fed up to hear of how bad is Man towards Nature and want to see some success stories of restoration. To exemplify the importance of this kind of projects in the urban landscape, this paper will analyze two industrial reclamation projects realized in Portugal during the last decade (Parque Tejo-Trancão - Expo 98 and Braga Stadium - Euro 2004). We will show how Man 're-building' the things he has destroyed makes people aware of what Man is doing to fix some of the Environment issues. The significance of these projects in achieving a sustainable urban landscape will be also discussed.

\section{FROM POST-INDUSTRIAL SITES TO MULTIFUNCTIONAL LANDSCAPES}

The history of the contemporaneous city was influenced by the accumulation of different visions, different urban models and mainly by significant changes in consumption and production patterns. The end of the twentieth century has brought a break in the industrial sector which brings with it an accelerating obsolescence of several industrial landscapes [11, 12]. The entire industrialized world is experiencing similar effects of the restructuring of the global economy, the automation of production processes, and the relocation of industry to areas characterized by low production costs.

This process termed 'deindustrialization' created severe economic, social and ecological repercussions [7, 13, 14]. The Industrial Era left behind a legacy of derelict landscapes. Urban core areas became economically disadvantaged, socially distressed and environmentally degraded through industrial contamination and process decline $[15,16]$. For this reason reclamation projects should redefine the post-industrial landscape through community-based, interdisciplinary action that integrates longer-term solutions based on social, cultural, economic and ecological objectives.

On the basis of the assumption above, the enhancement of the urban areas through the reclamation of the post-industrial metropolitan habitat, for an improvement of the quality of life supplies a series of plugs to achieve the sustainable town. The reclamation of these landscapes needs to be thought in terms of the reconnection town-nature, but knowing 'a priori' that greening is not enough to assist the rebirth of a place. More than greening, these landscapes need to be redeveloped in an integrative multifunctional way, emphasizing that sustainable landscapes should offer different multi-purpose uses, in order to be more attractive and viable.

For this reason several countries of the European Community (EC), as well as several states of the United States of America, have begun to embrace the notion that the industrial landscape offers unique opportunities to be redeveloped as multifunctional landscapes, viewing their value to society in a broad way. They discovered and recognized that more than ecological reclamation opportunities those sites embodied alternative social, cultural and economic values. Numerous recent international design competitions for the reuse of enormously scaled industrial sites all over the world have tried to promote sustainable development and build up multifunctional landscapes. Downsview Park, located at derelict military air base in Toronto and Fresh Kills reclamation project, the world's largest landfill on Staten Island, New York, are representative of these trends and present the most complete examples of landscape reclamation practices applied to the post-industrial sites in North America [17]. In Europe, various Landscape Architects, Planners and Urbanists worked hard for 10 years in the Ruhr Valley, Germany, exploring innovative possibilities for waste lands. Those competitions showed that perceptions concerning what constitutes reclamation has changed and now reflects environmentally cognizant sensibilities and contributions from a broad array of specialists [18] because more than greening it is necessary to create condition that attract people to those recycled landscapes. 


\section{PORTUGUESE ADVERTISED INDUSTRIAL LANDSCAPE RECLAMATION PROJECTS}

Even though the known relevance of post-industrial landscape reclamation projects to achieve sustainable development, in Portugal there is still a long way to go, once in the private sector view it is more cost effective to build new facilities than to renovate existing, older facilities. Therefore the reclamation projects that had been realized are several times associated with other events as it is the case of both case studies analyzed in this article. For this reason the current practice of post-industrial landscape redevelopment is primarily site-specific and driven by economic development motivations, which does not offer the full potential for sustainable reuse and revitalization that extends beyond property lines.

\subsection{Parque Tejo-Trancão - Expo 98}

Park Tejo-Trancão is one of the best examples of a post-industrial landscape reclamation project ever realized in Portugal (Fig. 1). It is located in the oriental part of Lisbon, in the right margin of the river Tejo, in a transition area between the municipal districts of Lisbon and Loures. Before being a park, this area was composed by several industrial structures (a landfill, scraps, a sewage treatment plant and some obsolete industrial buildings). The high indexes of contamination and degradation of this landscape, the proximity of the Natural Reserve of the Estuary of Tejo and the intention to develop the world exposition Expo'98 constituted decisive arguments for the intervention in this specific area. With approximated 90 ha, the park links physics and thematically with the Park Expo'98 [19].

The main objectives of the project were the creation of a new public space, redirecting the expansion of the city and re-establishing the relationship between city and river, the increase of the value of the residential complexes to be put up in the redevelopment area, the increase of public awareness through this kind of projects and the creation of a large green area within the city with several activities to all ages.

Ecological degradation and high pollution indexes, inherent to the former industrial occupation, created several soil, water and air contamination problems that at that time turned the project site into one of the most polluted sites in the Lisbon Metropolitan Area. For this reason, it was well thought-out necessary to create an experimental area that helped to identify the species that could be used at the project site taking into considering their resistance and adaptability to that environment.
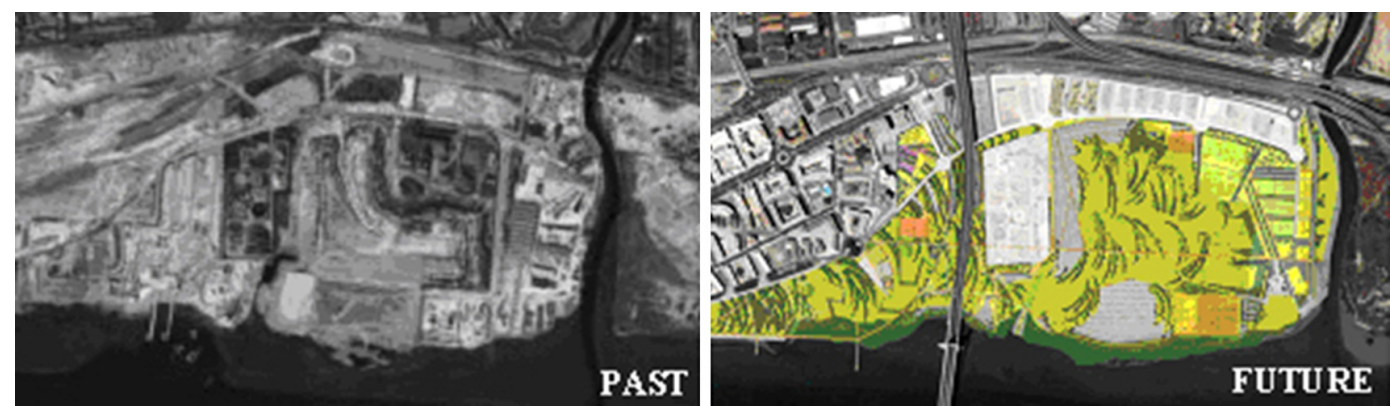

Figure 1: Past and future of the landscape of the Park Tejo-Trancão. 
Making part of this, the Park of Tejo-Trancão ambitioned to recover and defend both river's outlet, as well as, the ecological regeneration of the whole area, busy for pollutant and obsolete industrial facilities. This action, whose intent was the conversion of a degraded and obsolete space to a new multifunctional public place for the population of the city, would reveal a new landscape, a landscape hidden by dereliction. The park brought many benefits, once it implicated not only the decontamination and the greening of the place, but also the creation of attractive conditions, through the construction of a great multifunctional quality space where citizens could enjoy the riverfront area [20]. This is probably the reason why nowadays this space is one of the most utilized public spaces of the Metropolitan area of Lisbon.

The conceptual solution proposed by PROAP-studies and projects of Landscape Architecture and Hargreaves Associates analyzed the problems of the place, converting them into opportunities of artistic expression. Besides the ecological and functional sense of the proposed structure, the solution serves the parallel intention of establishing a spatial organization to translate a coherence and formal unit reading the group. The scenic values were also essential in the development of the concept of the park, supported by the creation of visual corridors and by the establishment of elevated platforms of observation of the exceptional views on the river and the marsh.

The project developed a unit that answered to the several selected uses of the program: sport recreation areas, sport competition areas, areas for cultural activities, passive recreation areas and environmental education areas. The sport recreation areas included tracks for bicycles, docks for fishing, ramps for small boats, thematic parks and an equestrian centre. The sport competition areas incorporated a golf academy, several tennis courts and informal lawns for active sports as soccer and rugby. The areas for cultural activities are informal spaces for musical exhibitions, theatre and any other cultural event [21]. In this way the elements of the program promoted flexibility for a wide range of activities by the creation of numerous informal spaces in the organization of the park, that provide varied social, cultural and physical activities.

The implementation of the park's project was proposed to be accomplished in three phases (Fig. 2), once the financing for its construction depended on the sales of the urban components of 'Vila Expo'. The first phase of the park corresponds to the construction of the south side of the park, which was accomplished during 1997. Once these works concluded, the reorganization of the elements of the project began. In this phase, the marsh areas, the location of the recreational facilities and the connections to the adjacent areas of the park and the plantations were defined. The works relating to the remaining areas contemplate a large natural area, utilization of which is assured by the introduction of several recreational facilities, and have a conclusion foreseen for 2010 [21].

This project has had a great importance to the Portuguese country once it showed that issues facing the industrialized world in regard to the reconstruction of the industrial landscape are multidimensional, involving cultural, social and economic ramifications, emphasizing the fact that greening is not enough, which is the main reason why it should be seen as an example for future interventions.

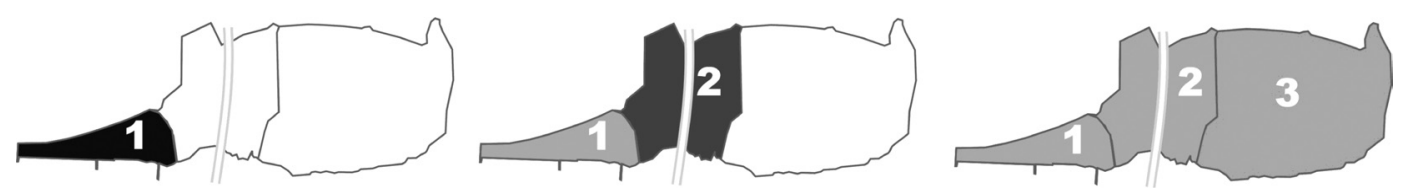

Figure 2: Landscape evolution of the Park Tejo-Trancão. (Adapted from Torrado [26]). 


\subsection{The quarry of Braga transformation to Stadium for Euro 2004}

The extractive industry implies, normally, a temporary use of a specific landscape, once this activity consists on the exploitation of non-renewable resources [22, 23]. So this activity usually leaves behind spaces with a huge potential to the creation of multifunctional landscapes, which is the example of the Braga Municipal Stadium (Fig. 3), which was created on the mountainside by leveling down a quarry of the mountain Monte Castro and served as a hosting venue for the Euro 2004 tournament. The project offers an unusual and innovative frame and the architecture is a sequence of sustainable decisions which should be listed and analyzed. The Braga Stadium was projected by the architect E. Souto Moura and constructed in a derelict quarry located in the urban area of Braga in the North of Portugal. The stadium is just a part of the sports complex built in an area occupying more than 74 acres. A space that includes the stadium, olympic pools, and several other multifunctional facilities all linked by numerous accesses where it is possible to contact with nature, feeling the spirit of the old landscape - the quarry. The vegetation was used to increase the quality of the place by creating alignments that direct people to the different areas of the project.

The main public access is located to the North, by means of a parking esplanade, the dimensions of which are controlled by means of a netted plantation. From the esplanade, climbing the gentle slope, we approach the Stadium diagonally, accompanied by its foreshortened lateral views, emphasized by the use of different types of plantations. From this point of view, the Stadium appears as a concave recipient, as an open vessel, later perceiving the interior space and the surrounding structure. Ascending the gentle slope, the foreshortened figures are transformed into a frontal vision of the North Stand's concrete structure [24].
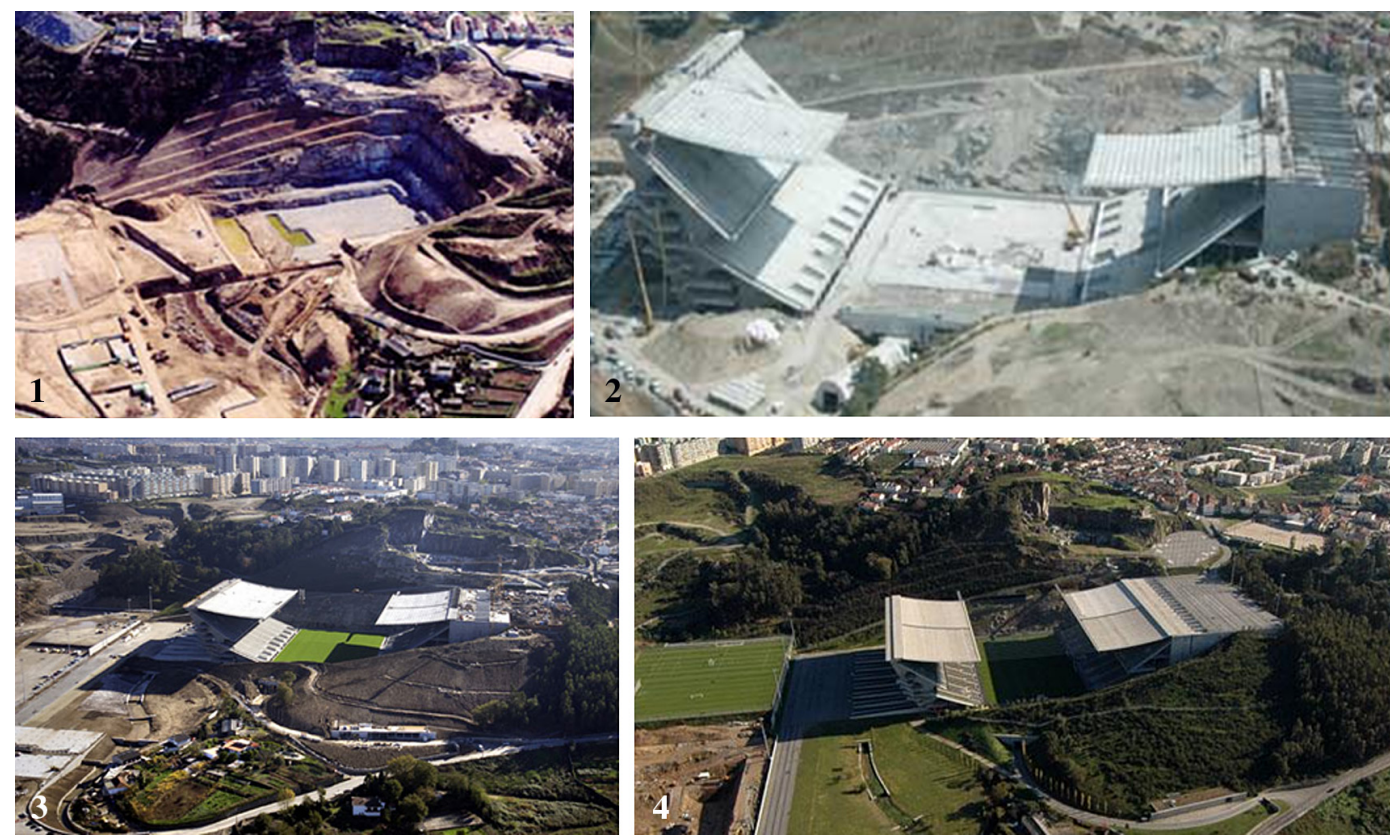

Figure 3: Aerial view of four different phases of the transformation of the quarry into the Braga Stadium after reclamation. 
This visual conflict between the geometric and formal expressiveness of the stadium and the natural, shapeless walls which surround it, finally find a point of synthesis in the pressured roof, in which the cables (symbolizing the bridges that were constructed by the Inca civilization) deformed by the weight are able to camouflage the repetitive sequence in the changing texture of its natural environment. In this specific project architecture and its surroundings were treated as the same thing, at least from the Landscape Architecture point of view. Both, architecture and its environment are constructed using the same techniques, to reach the same goal, to construct a unique balance. They are only differentiated by their degree of visibility, in their desire to appear present or unperceivable, formal or environmental. This option enables the opportunity to create a multifunctional landscape, emphasizes the great possibilities that lay beneath a derelict post-industrial landscape and showed that multifunctional reclamation project of these landscapes are more sustainable and cost effective than the usual greening option, not only because it creates conditions to different types of uses, but also, because it enables the achievement of sustainable development not only environmentally, but also culturally, socially and economically. For this reason the Braga Stadium project is an example for future interventions once it used derelict land to create premium urban space minimizing the environmental and aesthetical impacts of the former industrial activity.

\subsection{SWOT analysis}

To understand the relevance of landscape reclamation in both locations, a SWOT analysis was developed, in order to analyze the Strengths, Weaknesses, Opportunities and Threats present in this landscape, considering cultural, economic and environmental aspects (Tables 1 and 2).

Table 1: SWOT analysis for the Parque Tejo-Trancão - Expo 98.

\begin{tabular}{ll}
\hline & Waterfront landscape \\
& Great affluence to the city new green spaces \\
National and international tourism & Integrated in the Lisbon City Plan of Rio Tejo \\
& Historic and natural resources value \\
& Heritage value of the memory of the place \\
& Aging and decreasing population \\
& Insufficient investments \\
& Isolated urban space \\
Weaknesses & Lack of public transportation \\
& Creation of greenways \\
& Creation of an environmental attraction (oceanarium) \\
& Heritage and tourism \\
Opportunities & Investment in cultural equipment \\
& New residential area \\
& Floods \\
& Air and soil pollution \\
& Degradation of the industrial structures \\
& Suburbanization and aging population \\
& Lack of employment
\end{tabular}


Table 2: SWOT analysis for the quarry of Braga transformation to Stadium for Euro 2004.

\begin{tabular}{ll}
\hline \multirow{3}{*}{ Strengths } & Amphitheatric location \\
& Historic and natural resources value \\
& Price of land \\
Weaknesses & Insufficient investments \\
& Deficient public transportation network \\
& Reduced infrastructures of leisure \\
& Efficient use of the local heritage in the tourism \\
Opportunities & Attractive industrial heritage \\
& Investment in cultural equipment \\
& Coordinate use of regional funds \\
& Isolated development \\
& Decreasing young population \\
Threats & Lack of employment \\
& Uncertain future and state politics \\
\hline
\end{tabular}

\section{CONCLUSIONS}

The reclamation projects of derelict industrial areas should follow design principles that promote sustainability, reduce negative environmental impacts, and foment economic prosperity, social inclusion, multifunctionality and better quality of life. For this reason reclamation projects should reinforce landscape character taking into consideration the spirit of the place and integrating the preindustrial existence in the new multifunctional landscape, in order to achieve sustainable development, not only environmentally, but also culturally, socially and economically [25].

After the analyses of this article it is concluded that in Portugal postindustrial landscapes are commonly experienced negatively as fragmented and incoherent spaces. The projects presented constitute representative examples of post-industrial landscape reclamation in Portugal enabling a sense of spatial enlargement, with high degree of complexity, richness in discontinuities and with diverse ecological and social benefits, more than just greening the derelict site, these project had created conditions for different types of uses. Those values of conservation, making wise use of resources, and public participation in the planning process, are valid and defendable premises on which to base the reclamation process. Recovery efforts for the post-industrial landscape are mixed, producing various positive and negative impacts, satisfying various constituencies to certain extents with different formal and programmatic results.

\section{ACKNOWLEDGEMENTS}

The authors thank the support of Portuguese Foundation for Science and Technology (FCT) and also gratefully acknowledge the Research Centre for Spatial and Organizational Dynamics (CIEO), University of Algarve, for having provided the conditions to publish this work.

\section{REFERENCES}

[1] Corner, J., Terra Fluxus. The Landscape Urbanism Reader, Princeton Architectural Press: New York, pp. 21-33, 2006.

[2] Rossi, A., The Architecture of the City, MIT Press: Cambridge, MA, 1982. 
[3] Antrop, M., Background concepts for integrated landscape analysis. Agriculture Ecosystems and Environment, 77, pp. 17-28, 2000. doi:10.1016/S0167-8809(99)00089-4

[4] Pirelli, L., Progetto Bicocca, Edizioni Electa SpA: Milano, 1987.

[5] Frenchman, D., Connecting the Past to the Present. Urban Studies and Planning. MCP Thesis, MIT Press: Cambridge, MA, 1976.

[6] Loures, L., Horta, D., Santos, A. \& Panagopoulos, T., Strategies to reclaim derelict industrial areas. WSEAS Transactions on Environment and Development, 2(5), pp. 599-604, 2006.

[7] Allen, B. \& Linden, M., De-Industrialization: Social, Cultural and Political Aspects, University Press: Cambridge, 2002.

[8] Brebbia, A., Almorza, D. \& Klapperich, H., Brownfield Sites: Assessment, Rehabilitation \& Development, WIT Press: Southampton, 2002.

[9] Murungi, J., On the question of land: a philosophical perspective. Transformations of Urban and Suburban Landscapes, eds G. Backaus \& J. Murungi, Lexington Books: New York, 2002.

[10] Collins, T., Art and ecological restoration in cities. Urban Futures, eds T. Hall \& M. Miles, Routledge: London, 2001.

[11] Jameson, F., Postmodernism, or, the Cultural Logic of Late Capitalism, Duke University Press: Durham, NC, 1991.

[12] Sieverts, T., Cities Without Cities: an Interpretation of the Zwischenstadt, Spon Press: London \& New York, 2003.

[13] Mostafavi, M. \& Najle, C., Landscape Urbanism - A Manual for the Machinic Landscape, Architectural Association Publications: London, 2003.

[14] Berger, A., Drosscape - Wasting Land in Urban America, Princeton Architectural Press: New York, 2006.

[15] Page, W., Contaminated Sites and Environmental Cleanup: International Approaches to Prevention, Remediation and Reuse, Academic Press: San Diego, 1997.

[16] Kirkwood, N., Manufactured Sites: Integrating Technology and Design in Reclaimed Landscapes, Taylor \& Francis: New York, 2001.

[17] Waldheim, C., Landscape as urbanism. The Landscape Urbanism Reader, Princeton Architectural Press: New York, pp. 35-53, 2006.

[18] Burley, J., Environmental Design for Reclaiming Surface Mines, The Edwin Mellen Press: New York, 2001.

[19] (CLWE) Commissariat of the 1998 Lisbon World Exposition, The Green Book, Fernandes e Terceiro: Lisboa, 1998.

[20] Loures, L. \& Panagopoulos, T., Sustainable reclamation of industrial areas in urban landscapes. WIT Transactions on Ecology and Environment, 102, pp. 791-800, 2007.

[21] PROAP \& Hargreaves Associates, Parque do Tejo e do Trancão. Arquitecti, 30, pp. 1-13, 1995.

[22] Harris, J., Birch, A. \& Palmer, J., Land Restoration and Reclamation-Principles End Practice, Addison Wesley Longman: London, 1996.

[23] Bradshaw, A., Handbook of Ecological Restoration, Volume 1 - Principles of Restoration, eds M.R. Perrow \& A.J. Davy, Cambridge University Press: Cambridge, 2002.

[24] Moura, E., Braga Municipal Stadium. Municipality of Braga: Braga, http://www.afaconsult. com/, 20-01-2007, 2003.

[25] Loures, L., Santos, R. \& Panagopoulos, T., Urban parks and sustainable development - the case study of Portimao City, Portugal. Proceedings of the Int. Conf. on Energy, Environment, Ecosystems \& Sustainable Development, July 24-26, 2007, Agios Nikolaos, Greece, pp. 127-131, 2007.

[26] Torrado, M., 2007. Paisagens Recicladas. Final Degree Thesis, University of Algarve, Faro, Portugal (in Portuguese). 